\title{
Radiocarbon chronology of Late Pleistocene large mammal faunas from the Pannonian basin (Hungary)
}

\author{
JÁNOS KOVÁCS
}

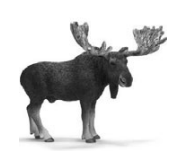

\begin{abstract}
Geochronological data from the mammal fauna of the Pannonian basin during the Late Pleistocene are compiled. Thirty-four megafaunal samples (including both fossil bone and associated materials such as charcoal), previously radiocarbon dated by accelerator mass spectrometry and conventional methods, range from 43 to $10.3{ }^{14} \mathrm{C} \mathrm{ka} \mathrm{BP}$ (47-13 ka cal BP). Thus, most samples date within Marine Isotope Stage (MIS) 3 and 2 of the Late Pleistocene, and indicate that the mammoth steppe fauna was able to colonize this region during a period of rapid environmental change. The radiocarbon evidence fits well into the known colonization pattern of the mammoth steppe and shows a continuous distribution in the Late Weichselian grassland areas of East Central Europe. $•$ Key words: megafauna, extinction, late Quaternary, East Central Europe, climate change.
\end{abstract}

KoVÁCS, J. 2011. Radiocarbon chronology of Late Pleistocene large mammal faunas from the Pannonian basin (Hungary). Bulletin of Geosciences 87(1), 13-19 (2 figures, 1 table). Czech Geological Survey, Prague. ISSN 1214-1119. Manuscript received May 12, 2011; accepted in revised form August 29, 2011; published online November 30, 2011; issued February 29, 2012.

János Kovács, Department of Geology, University of Pécs, Ifjúság útja 6, H-7624 Pécs, Hungary; jones@gamma.ttk.pte.hu

The cold-adapted large mammals, also known as Mammuthus-Coelodonta Faunal Complex (Kahlke 1999), which were common in a wide area of Eurasia during the Late Pleistocene, also existed in the Pannonian basin (Fig. 1). The presence of these cold-adapted mammalian faunas is common in the fossil record of the region (Szabó 1873, Schafarzik 1884, Jánossy 1986, Vörös 1987, Schréter 1917, Kretzoi 1942, Jánossy \& Vörös 1979, Konrád et al. 2010, Varga et al. 2010, Katona et al. in press). Despite the abundance of such fossils, few specimens have been radiometrically dated. Where site studies have been performed, they have typically been geographically restricted and have not examined population/extinction dynamics in the wider Pannonian basin. Furthermore, many such works have not been internationalized, having being published only in Hungarian language journals and theses. Jánossy (1986) and Pazonyi (2004) previously reviewed the fossil record (including radiocarbon dating) of the Late Pleistocene Pannonian basin. The book authored by Jánossy (1986) describes all animal assemblages of the Hungarian Pleistocene deposits, with complete faunistic lists and with detailed explanation of the stratigraphical arrangements. In the paper by Pazonyi (2004), examination of communities is based on ecotype analysis that employs trophic preferences and body size of species, as well as species richness of communities. This latter study is based mainly on microvertebrate findings in cave deposits.
In the present paper additional radiocarbon dates (e.g. studies in Hungarian: Vörös 1989, Krolopp et al. 1995, Sümegi et al. 1998, Pazonyi 2006, Ringer et al. 2006) that update and complete (e.g. archeological studies: Vörös 1991, 2000; Dobosi \& Hertelendi 1993; Hertelendi 1993; Adams 2002; Dobosi 2006) this information are provided. A key to understanding Late Pleistocene megafaunal extinction dynamics is knowledge of megafaunal ecological response(s) to long-term environmental perturbations. Late Pleistocene vertebrate fossil localities from Hungary allows for testing of anthropogenic versus climate change megafauna extinction hypotheses. These chronologies have been correlated with the published paleoclimatic knowledge of the Late Pleistocene in the Pannonian ba$\sin$.

Abbreviations. - Marine Isotope Stage - MIS; Greenland Stadials - GS

\section{Materials and methods}

The selected taxa are the following species: woolly mammoth (Mammuthus primigenius Blumenbach, 1799), cave bear (Ursus spelaeus Rosenmüller, 1794), reindeer (Rangifer tarandus Linnaeus, 1758), elk (Alces alces Linnaeus, 1758) and wild horse (Equus sp. Linnaeus, 1758). The 


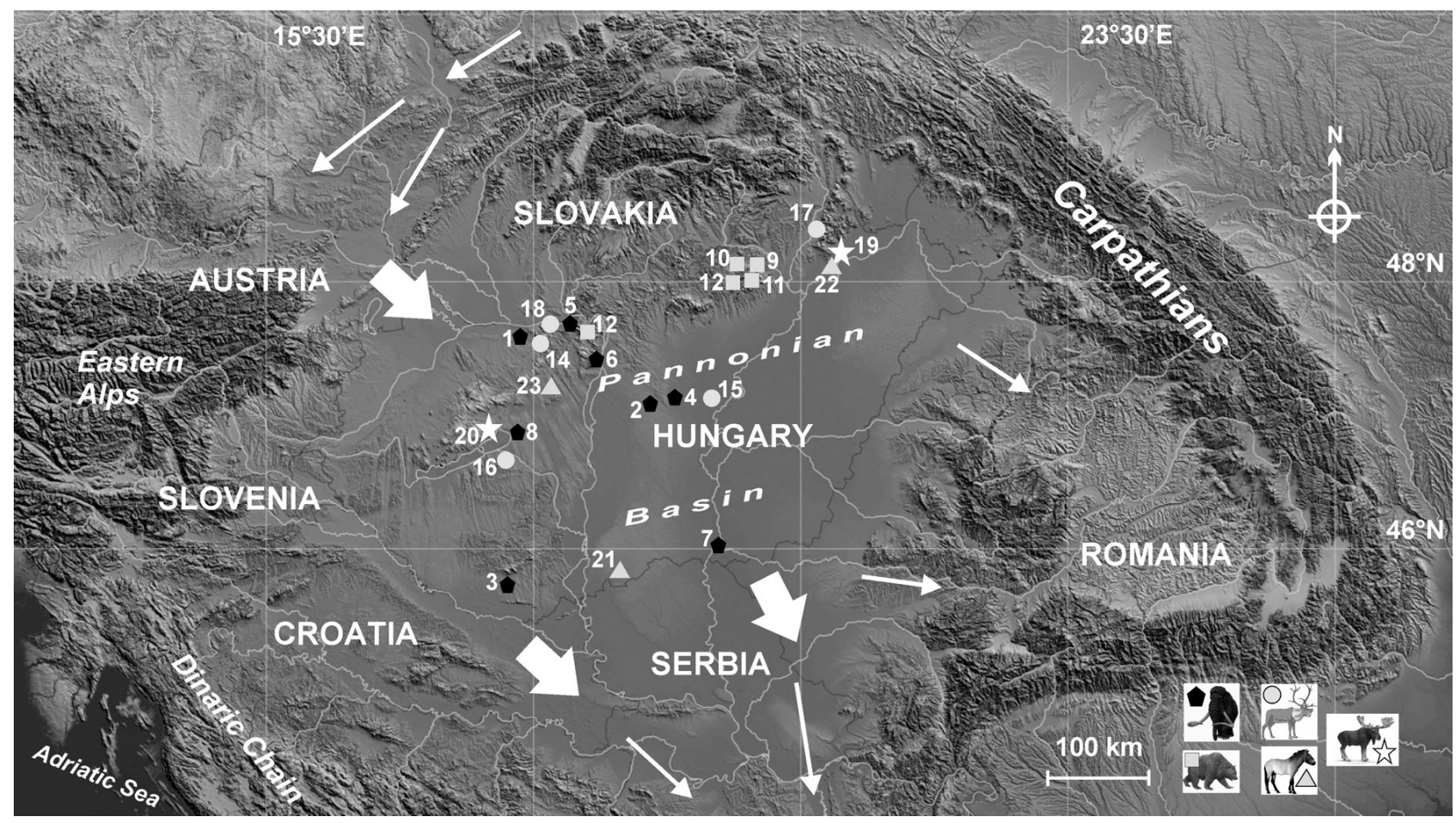

Figure 1. Location of paleontological and archaeological sites cited in the table and Fig. 2. The white arrows indicate generally accepted migrations of large mammals in the Late Pleistocene (Kahlke 1999, Svoboda et al. 2005).

large-bodied mammal record presented here was compiled by the author from published papers and reports, and includes over 20 fossil deposits (Fig. 1) that contain dental and postcranial elements. A total of 34 radiocarbon dates was documented; majority of the dated materials are teeth and bones as well as charcoal (Table 1). Of the dates, three were previously published by the author (but one is only a corroborated date which is not included in the table), and 32 by other researchers. Some dates are presented for the first time here in an English language international journal. Most of the specimens (22) were dated using conventional radiocarbon dating and 12 using accelerator mass spectrometry (AMS). Radiocarbon ages are quoted both uncalibrated and in calendar years (calibrated using CalPal-2007 software; Danzeglocke et al. 2011). The results are in summarized in Table 1. Since the specimens were dated in different laboratories over a period of time, the methods used for pre-treatment and dating vary. This adds an element of uncertainty in comparing dates. On the other hand, compiling results from different dating laboratories maximizes the information content in the study. It is also known that the reliability of radiocarbon dates decreases beyond $30 \mathrm{ka}$, so such dates should be treated with caution. The problem should be less critical for dates performed more recently, especially by AMS; but there are always exceptions. A recent study by Price et al. (2011) found major problems with AMS dating beyond $30 \mathrm{ka}$. Information on the vegetation and environmental conditions relating to mammoth steppe habitats in the study region has been obtained from earlier published biostratigraphical (Vörös 1987), paleoecological (Pazonyi 2004, 2006), pleolimnological (Hetényi et al. 2010), and paleobotanical (Rudner \& Sümegi 2001) records.

\section{Radiocarbon data of the megafauna}

\section{Mammuthus primigenius}

Fossil remains of woolly mammoth are common in Hungary; ca 400 specimens have been recovered, including are six complete skeletons (Vörös 1981, Konrád et al. 2010). However, radiocarbon dates are available for only seven specimens (Figs 1, 2). The oldest occurrence woolly mammoth in the Pannonian basin is uncertain, but seems to correspond with the end of the Middle Pleistocene or the first episodes of the Late Pleistocene (Vörös 1981, Jánossy 1986). The first dated appearance of $M$. primigenius is $c a$ 50-36 ka in Hungary (Vörös 1981). The Csajág mammoths represent the youngest known and most complete records of woolly mammoth in Hungary (Katona et al. 2010, in press). The Csajág date (15.8-16.7 ka cal BP) is important in that it provides the youngest firmly dated record of mammoths in Hungary. The recently published date on an adult tooth is the youngest mammoth date from Hungary; the others are slightly older date at 19,099 \pm 248 cal a BP 
Figure 2. Chronological distribution of the Late Pleistocene cold-adapted large mammal finds in Hungary compared to the GRIP paleoclimatic oxygen curve and the marine isotope stages (MIS). The vertical blue bands indicate the main cold episodes: Greenland Stadials (GS).

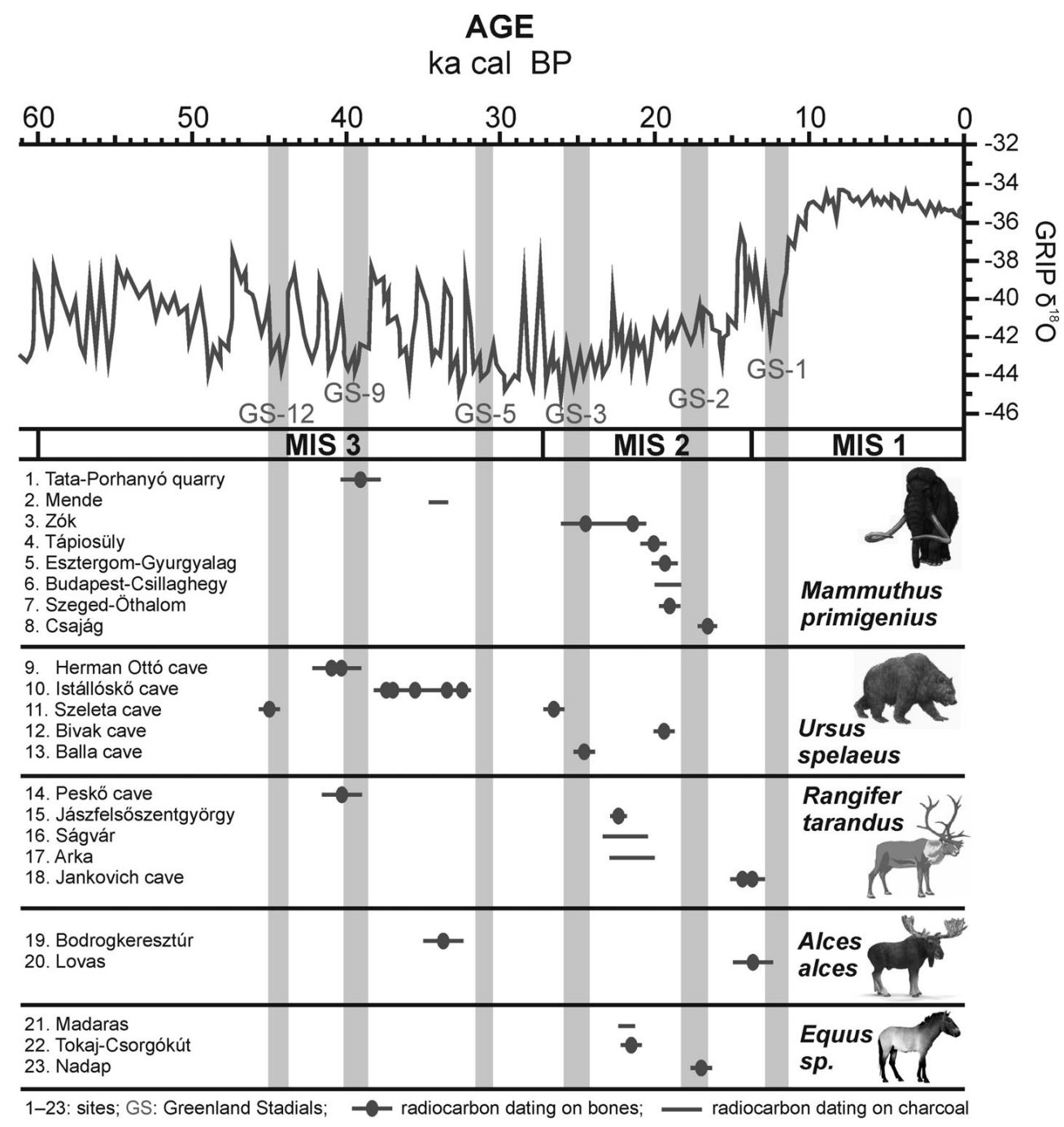

ka cal BP from Szeged-Öthalom (Krolopp et al. 1995), and 19,354 \pm 354 cal a BP from Esztergom-Gyurgyalag (Vörös 1991). However, these finds are only bone fragments from Late Upper Gravettian (Epigravettian) culture layers. In contrast, the Csajág remains (together with Zók remains, 21,250 4450 cal a BP; Konrád et al. 2010) associated skeletons in stratified context, provide clear evidence that the mammoth was native to Hungary at this time. Based on the known dates, the woolly mammoth disappeared entirely from the Pannonian basin ca 16,000 yrs ago.

\section{Ursus spelaeus}

The cave bears (Ursus spelaeus group) are extinct ursids of wide European and Asian distribution (Pacher \& Stuart 2009). Karst depressions and caves were the source for most of the important early discoveries of extinct Pleistocene animals such as cave bears (Kempe \& Döppes 2009). Middle Pleistocene fossil remains of $U$. spelaeus have been found in the Suba-Lyuk cave in Hungary (Jánossy 1986). This species inhabited the northern mountainous area (the cave sites presented here; Fig. 1) of Hungary throughout the greater part of the Late Pleistocene. The radiocarbon dates of cave bears are between 46 and $19.5 \mathrm{ka}$ cal BP (Table 1). A molar and a bone fragment of a cave bear were selected for radiocarbon dating from the Herman Ottó cave. Both specimens are $\mathrm{ca} 41 \mathrm{ka}$ cal BP: the oldest AMS ${ }^{14} \mathrm{C}$ dated cave bear finds. Another specimen was dated $46,580 \pm 1466$ cal a BP from Szeleta cave using conventional measurement. Pacher \& Stuart (2009) suggested that the cave bear had disappeared about $27.8 \mathrm{ka}$ cal BP. Therefore, it is possible that the specimen dated 19,169 $\pm 318 \mathrm{cal}$ a BP in the Bivak cave is too young, and hence not a cave bear. It remains possible that it was misidentified, perhaps confused with brown bear (U. arctos). The period from GS 9 (in MIS 3) until GS 5 was characterized by the absolute predominance of the cave bear in the Pannonian basin (Fig. 2). The youngest, dated U. spelaeus (with accompanying fauna like Crocuta crocuta spelaea) is from the Balla 
cave which age is 24 ka cal BP (Vogel \& Waterbolk 1972). The fossil bearing layer is overlain by yellow clay containing Magdalenian tools and human remains (Vörös 1987, age: $18,150 \pm 200 \mathrm{ka} \mathrm{BP}$, Geyh et al. 1969). Climatic cooling, coupled with decreased vegetational productivity were probably responsible for its disappearance from this region (Stuart \& Lister 2007, Pacher \& Stuart 2009). There is little or no convincing evidence of human involvement in cave bear extinction (Pacher \& Stuart 2009).

\section{Rangifer tarandus}

Fossil remains of Rangifer tarandus from the last glacial of Eurasia are extremely common (Kahlke 1999). Close to the Csajág mammoth site ( ca $30 \mathrm{~km}$ to the south) a Gravettian reindeer hunters' campsite was discovered at Ságvár and was dated to 21-20 ka cal BP (Vörös 1982). The reindeer is the most common cold-adapted large mammal species found in Hungarian Pleistocene sites, with most remains occurring within archaeological contexts (Vörös 1982, 1987). The abundance of reindeer bones discovered in Hungarian sites of the Gravettian culture has led prehistorians to consider that these hunter-gatherer groups were highly dependent on this animal resource (Vörös 1982, Dobosi 2005). The oldest, dated $R$. tarandus is from the Peskó cave which age is $\sim 40 \mathrm{ka}$ cal BP (Vogel \& Waterbolk 1972). The reindeer generally occurs in large numbers in every site. The majority of dated specimens are from MIS 2.

\section{Alces alces}

Elk (Alces alces) were among the first large mammals to recolonize Central Europe after the last glaciation (Kahlke 1999, Schmölcke \& Zachos 2005). Already during the Allerød they established themselves in most parts of the area. In the early Holocene their distribution range extended from the Pyrenees to Denmark and from Austria to Great Britain and also covered East Central Europe where they still occur today (Schmölcke \& Zachos 2005). Elk finds are also common is the Pannonian basin, although only two specimens have been radiocarbon dated (Fig. 2). An almost complete skeleton of Alces brevirostris that was discovered in Ördöglyuk cave in the vicinity of Budapest is of special importance. It was dated to MIS 12 (Vörös 1985). Kahlke (1999) suggested that Alces brevirostris is possible ancestor of modern elk. The oldest directly dated find is from an open-air site in the surroundings of Bodrogkeresztúr ( $c$ a $33 \mathrm{ka} \mathrm{cal} \mathrm{BP).} \mathrm{Last} \mathrm{appearance} \mathrm{(absolute} \mathrm{dated)} \mathrm{of}$ elk in the Pannonian basin is from the end of MIS 2 (13.5 ka cal BP).

\section{Equus sp.}

Within the early Middle Pleistocene, the caballoid horses (Equus spp.) rapidly became the dominant group in the Pannonian basin as well. In the brickyard of Madaras (Fig. 1) many fossil specimens were unearthed (Vörös 1989). Although maxillary bones with teeth and postcranial bones including the pelvis were recovered, only associated charcoal has been dated ( $c a 21.6 \mathrm{ka}$ cal BP). Some bones of Equus germanicus were found in loess deposit near Tokaj. The age of the recovered specimens is $20 \mathrm{ka} \mathrm{cal}$ BP (Sümegi \& Hertelendi 1998). A fossil faunal assemblage discovered near Nadap is dominated by horse (Dobosi \& Hertelendi 1993.) Radiocarbon dates have been obtained on horse phalange from this site, of which age is 16 ka cal BP (Dobosi \& Hertelendi 1993).

\section{Paleoenvironment, paleogeography and megafaunal extinction}

The occurrence of the mammoth steppe fauna between 46 and $13 \mathrm{ka}$ cal BP in Hungary was not a singular biogeographic event. During this time span the animals repeatedly occupied steppe-like landscapes of the Carpathian (Pannonian) basin, when sufficient resources were present to allow their subsistence.

Although no mammoth steppe fauna has been radiocarbon dated between GS 5 and GS 3 (33-25 ka), it is possible that this is simply an artefact of sampling. According to Rudner \& Sümegi (2001), in this time interval, the climatic conditions during the summer period in the Pannonian basin were similar to those prevailing today. Based on the malacothermometer method, the mean July temperature was calculated and values are $18-19{ }^{\circ} \mathrm{C}$ for the southern parts of the Pannonian basin and $16-17^{\circ} \mathrm{C}$ for the northern part of Hungary (Sümegi \& Krolopp 2002). Between 27 and $25 \mathrm{ka}$ cal BP a significant change in environmental conditions for the Pannonian basin can be traced, initiating the process of loess formation (Újvári et al. 2010). This change refers to a significant cooling and development of a cold continental steppe-forest steppe environment with tundra-like spots in Hungary (Sümegi \& Krolopp 2002). Two cool treeless-steppe periods existed between 25 and $12 \mathrm{ka}$ cal BP (25-23 ka BP and 20-18 ka BP). In this period 'microinterstadials' were described by Rudner \& Sümegi (2001), dated to 23-20 ka cal BP and 18-16 ka cal BP. The occurrence of the microinterstadial is further supported with biogeochemical proxies, including plant-derived biomarkers and stable $\mathrm{C}$ and $\mathrm{N}$ isotopes (by Schatz et al. 2011). This short phase of a warmer, wetter climate was characterized by an increase in the abundance of intermediate and woodland-dwelling mollusks, suggesting the development of a 
Table 1. AMS ${ }^{14} \mathrm{C}$ and conventional radiocarbon dates of large mammal remains from the Pannonian basin.

\begin{tabular}{|c|c|c|c|c|c|c|c|}
\hline $\begin{array}{l}\text { No. Figs } \\
1 \text { and } 2\end{array}$ & Location & Species & Dated material & Lab code & ${ }^{14} \mathrm{C}$ a BP $\pm 1 \sigma$ & cal a $\mathrm{BP} \pm 1 \sigma$ & Reference \\
\hline 1 & Tata-Porhanyó quarry & Mamm. p. & charred bone & GrN-3023 & $33,330 \pm 900$ & $38,369 \pm 1707$ & Vogel \& Waterbolk (1967) \\
\hline 2 & Mende & Mamm.p. & charcoal & Mo-422 & $29,800 \pm 600$ & $33,968 \pm 531$ & Vinogradov et al. (1968) \\
\hline 3 & Zók & Mamm. p. & tusk* & AA-80678 & $17,760 \pm 200$ & $21,250 \pm 450$ & Konrád et al. (2010) \\
\hline 4 & Tápiósüly & Mamm. p. & tooth & Hv-1615 & $16,750 \pm 400$ & $20,060 \pm 528$ & Geyh et al. (1969) \\
\hline 5 & Esztergom-Gyurgyalag & Mamm. p. & bone & Deb-1160 & $16,160 \pm 200$ & $19,354 \pm 354$ & Vörös (1991) \\
\hline 6 & Budapest-Csillaghegy & Mamm. p. & charcoal & Deb-3160 & $15,935 \pm 150$ & $19,109 \pm 241$ & Sümegi et al. (1998) \\
\hline 7 & Szeged-Öthalom & Mamm.p. & bone & Deb-3344 & $15,916 \pm 168$ & $19,099 \pm 248$ & Krolopp et al. (1995) \\
\hline 8 & Csajág & Mamm.p. & tooth* & GdA-2011 & $13,315 \pm 35$ & $16,249 \pm 413$ & Katona et al. (in press) \\
\hline \multirow{2}{*}{9} & Herman Ottó cave & Ursus spe. & tooth* & Beta-178806 & $35,410 \pm 660$ & $40,253 \pm 1008$ & Ringer et al. (2006) \\
\hline & Herman Ottó cave & Ursus spe. & bone* & Beta-178807 & $35,630 \pm 630$ & $40,426 \pm 1017$ & Ringer et al. (2006) \\
\hline \multirow{5}{*}{10} & Istállóskő cave & Ursus spe. & bone* & ISGS-A-0188 & $31,608 \pm 295$ & $35,536 \pm 493$ & Adams (2002) \\
\hline & Istállóskố cave & Ursus spe. & bone* & ISGS-A-0187 & $32,701 \pm 316$ & $37,219 \pm 717$ & Adams (2002) \\
\hline & Istállóskố cave & Ursus spe. & bone* & ISGS-A-0184 & $33,101 \pm 512$ & $37,600 \pm 884$ & Adams (2002) \\
\hline & Istállóskő cave & Ursus spe. & bone* & ISGS-A-0186 & $27,932 \pm 224$ & $32,447 \pm 320$ & Adams (2002) \\
\hline & Istállóskő cave & Ursus spe. & bone* & ISGS-A-0185 & $29,035 \pm 237$ & $33,520 \pm 359$ & Adams (2002) \\
\hline \multirow{2}{*}{11} & Szeleta cave & Ursus spe. & bone* & ISGS-A-0131 & $22,107 \pm 130$ & $26,574 \pm 409$ & Adams (2002) \\
\hline & Szeleta cave & Ursus spe. & bone & ISGS-4464 & $42,960 \pm 860$ & $46,580 \pm 1466$ & Adams (2002) \\
\hline 12 & Bivak cave & Ursus spe.? & bone & Gd-15614 & $15,970 \pm 270 ?$ & $19,169 \pm 318$ & Pazonyi (2006) \\
\hline 13 & Balla cave & Ursus spe. & bone & GrN-4661 & $20,000 \pm 190$ & $23,929 \pm 363$ & Vogel \& Waterbolk (1972) \\
\hline 14 & Peskố cave & Rangif. tar. & bone & GrN-4950 & $35,200 \pm 670$ & $40,112 \pm 983$ & Vogel \& Waterbolk (1972) \\
\hline 15 & Jászfelsôszentgyörgy & Rangif. tar. & bone & Deb-1674 & $18,500 \pm 400$ & $22,145 \pm 534$ & Hertelendi (1993) \\
\hline \multirow{4}{*}{16} & Ságvár & Rangif. tar. & charcoal & GrN-1783 & $18,900 \pm 100$ & $22,783 \pm 286$ & Vogel \& Waterbolk (1964) \\
\hline & Ságvár & Rangif. tar. & charcoal & GrN-1959 & $17,760 \pm 350$ & $21,302 \pm 587$ & Vogel \& Waterbolk (1964) \\
\hline & Ságvár & Rangif. tar. & charcoal & GrN-1957 & $17,400 \pm 100$ & $20,849 \pm 306$ & Vörös (1982) \\
\hline & Ságvár & Rangif. tar. & charcoal & GrN-1958 & $18,600 \pm 150$ & $22,212 \pm 353$ & Vörös (1982) \\
\hline \multirow{2}{*}{17} & Arka & Rangif. tar. & charcoal & A-518 & $18,700 \pm 190$ & $22,360 \pm 400$ & Haynes et al. (1966) \\
\hline & Arka & Rangif. tar. & charcoal & GrN-4038 & $17,050 \pm 350$ & $20,410 \pm 544$ & Vogel \& Waterbolk (1964) \\
\hline \multirow{2}{*}{18} & Jankovich cave & Rangif. tar. & bone & Gd-15626 & $12,440 \pm 230$ & $14,685 \pm 480$ & Pazonyi (2006) \\
\hline & Jankovich cave & Rangif. tar. & bone & Gd-15629 & $11,720 \pm 190$ & $13,632 \pm 241$ & Pazonyi (2006) \\
\hline 19 & Bodrogkeresztúr & Alces alces & bone/charcoal? & GX-195 & $28,700 \pm 300$ & $33,170 \pm 467$ & Vörös (2000) \\
\hline 20 & Lovas & Alces alces & bone* & ETH15199 & $11,740 \pm 100$ & $13,623 \pm 157$ & Dobosi (2006) \\
\hline 21 & Madaras & Equus sp. & charcoal & Hv-1619 & $18,080 \pm 405$ & $21,676 \pm 589$ & Vörös (1989) \\
\hline 22 & Tokaj-Csorgókút & Equus sp. & bone & Deb-2722 & $16,940 \pm 250$ & $20,254 \pm 446$ & Sümegi \& Hertelendi (1998) \\
\hline 23 & Nadap & Equus sp. & phalange* & GrA-16563 & $13,050 \pm 70$ & $15,939 \pm 398$ & Dobosi \& Hertelendi (1993) \\
\hline
\end{tabular}

*AMS dating; ? - taxon questionable, most likely U. arctos

forest-steppe environment with significantly more trees than in the preceding periods (Sümegi \& Krolopp 2002, Schatz et al. 2011).

Those data suggest that during the cold continental

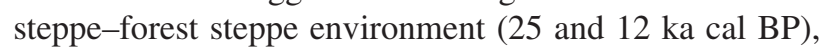
the Pannonian basin had an extremely continental arid climate with a small amount of solid precipitation, possessed firm soil, and was dominated by open plant communities (herb, grass and low shrubs) and some trees. But there were also intervals (e.g. 18-16 ka BP) in which trees and shrubs expanded, so called tree-steppe or 'open parkland' environment (Schatz et al. 2011).

The cause or causes of late Quaternary megafaunal extinction continue to be debated (Koch \& Barnosky 2006). Large herbivorous vertebrates have strong interactions with vegetation, which may consequently affect the structure, composition and dynamics of plant communities in many ways (Johnson 2009). Herbivory converted stands of tall forest into open parkland or grassland by suppressing woody regeneration; these open areas would be invaded by 
thickets of thorny scrub resistant to browsing, which, in turn, provided patchy refuges where seedlings of palatable trees could re-establish; emergent trees then shaded out under storey scrubs and grew into forest stands destined to repeat the cycle (Johnson 2009). The limited data available so far indicate the probable extinction of the cave bear before $c a 24 \mathrm{ka}$ cal BP, and woolly mammoth $\mathrm{ca} 16 \mathrm{ka}$ cal BP in the Pannonian basin. The patterns of last occurrence of such taxa strongly indicate a close relationship between vegetational changes (in response to climatic changes) and distributional shifts prior to extinction (Stuart \& Lister 2007). Data from Hungarian excavations do not support the blitzkrieg or attritional overkill hypotheses, which suggest that the losses should have occurred over short timescales of only 500-1500 years (Barnosky et al. 2004). The possible role of humans in limiting the natural expansion of these species requires further investigation.

The lowlands of Lower Austria - Moravia - South Poland form an important natural corridor in Central Europe, allowing migrations of both animals and humans between the Danube valley and the North European Plain (Svoboda et al. 2005). The Morava River valley runs in a roughly south-to-north direction, connecting, via the Danube and Tisa River valleys, the Hungarian Pannonian Plain through Serbia (via the Vardar River valley in Macedonia) to northern Greece in the south (Fig. 1). The large mammals probably used this route for dispersal in the Late Pleistocene. The Pannonian basin was an interesting and important "transition-region" with refugial character as well as distribution of typical Pleistocene faunal elements.

\section{Acknowledgements}

The author thanks Piroska Pazonyi for radiocarbon dates from her $\mathrm{PhD}$ thesis. The paper greatly benefited from the constructive comments and suggestions of Gilbert J. Price (School of Earth Sciences, The University of Queensland) and Pavel A. Kosintsev (Institute of Plant and Animal Ecology, Urals Branch of the RAS).

\section{References}

ADAms, B. 2002. New Radiocarbon Dates from Szeleta and Istállóskô Caves, Hungary. Praehistoria 3, 53-55.

Barnosky, A.D., Koch, P.L., Feranec, R.S., Wing, S.L. \& ShaBEL, A.B. 2004. Assessing the causes of Late Pleistocene extinctions on the continents. Science 306, 70-75.

DOI 10.1126/science.1101476

BlumENBACH, J.F. 1799. Handbuch der Naturgeschichte. 559 pp. Johann Christian Dietrich, Göttingen.

DANZEGlocke, U., Jöris, O. \& Weninger, B. 2011. CalPal-2007 online. http://www.calpal-online.de/, accessed 2011-01-15.

Doвosi, V.T. 2005. Cadastre of palaeolithic finds in Hungary. Communicationes Archaeologicae Hungariae 2005, 49-81.
Doвosi, V.T. 2006. Lovas (Hungary) ochre mine reconsidered. Der Anschnitt - Zeitschrift für Kunst und Kultur im Bergbau 19, 29-36.

Dobosi, V.T. \& Hertelendi, E. 1993. New C-14 dates from the Hungarian Upper Palaeolithic. Préhistoire Européenne 5, $135-141$.

Geyh, M.A., Schweitzer, F., Vértes, L. \& Vogel, J.C. 1969. Neue chronologische Angaben der Würm-Vereisung in Ungarn. Földrajzi Értesító 18, 5-18.

Haynes, C.V., JR., Damon, P.E. \& Grey, D.C. 1966. Arizona radiocarbon dates VI. Radiocarbon 8, 1-21.

HERTELENDI, E. 1993. Radiocarbon age of a bone sample from the upper paleolithic settlement near Jászfelsőszentgyörgy. Tiscium 8, 61-62.

HetéNyi, M., Nyilas, T. \& SAJgó, Cs. 2010. Organic geochemical evidence of late Pleistocene-Holocene environmental changes in the Lake Balaton region (Hungary). Organic Geochemistry 41, 915-923. DOI 10.1016/j.orggeochem.2010.01.004

JÁnossy, D. 1986. Pleistocene Vertebrate Faunas of Hungary. 208 pp. Developments in Palaeontology and Stratigraphy. Elsevier, Amsterdam.

JÁnOSSY, D. \& VöRös, I. 1979. Grossäuger - Streufunde aus dem Pleistozän Ungarns. Fragmenta Mineralogica et Palaeontologica 9, 21-60.

Johnson, C.N. 2009. Ecological consequences of Late Quaternary extinctions of megafauna. Proceedings of the Royal Society B (Biological Sciences) 276, 2509-2519.

DOI 10.1098/rspb.2008.1921

KAHLKE, R.-D. 1999. The History of the Origin, Evolution and Dispersal of the Late Pleistocene Mammuthus-Coelodonta Faunal Complex in Eurasia (Large Mammals). 219 pp. Fenske Companies, Rapid City.

Katona, L., Kovács, J., Kordos, L., Linkai, I. \& Magyari, Á. 2010. Two young woolly mammoths findings near Lake Balaton, Hungary. Quaternaire, Supplement 3, 75-77.

Katona, L., Kovács, J., Kordos, L., Szappanos, B. \& Linkai, I. in press. The Csajág mammoths (Mammuthus primigenius) Late Pleniglacial finds from Hungary and their chronological significance. Quaternary International, 1-9.

DOI 10.1016/j.quaint.2011.01.048

KemPE, S. \& DöPPES, D. 2009. Cave bear, cave lion and cave hyena skulls from the public collection at the Humboldt Museum in Berlin. Acta Carsologica 38, 253-264.

Koch, P.L. \& Barnosky, A.D. 2006. Late Quaternary Extinctions: State of the Debate. Annual Review of Ecology, Evolution, and Systematics 37, 215-250.

DOI 10.1146/annurev.ecolsys.34.011802.132415

Konrád, G., Kovács, J., Halász, A., Sebe, K. \& PÁlfFy, H. 2010. Late Quaternary woolly mammoth (Mammuthus primigenius Blum.) remains from south Transdanubia, Hungary. Comptes Rendus Palevol 9, 47-54. DOI 10.1016/j.crpv.2009.08.001

KretzoI, M. 1942. Spelaeus-fauna aus dem Mecsek-Gebirge ohne Höhlenbaren. Földtani Közlöny 72, 364-364.

Krolopp, E., Sümegi, P., Kuti, L., Hertelendi, E. \& Kordos, L. 1995. Palaeoecological reconstruction of formation of the Szeged-Öthalom area loess formations. Földtani Közlöny 125, 309-361.

Linnaeus, C. 1758. Systema Naturae per Regna Tria Naturae, secundum Classes, Ordines, Genera, Species, cum Charac- 
teribus, Differentiis, Synonymis, Locis. Tomus I. 823 pp. Laurentii Salvii, Holmiae (Stockholm).

Pacher, M. \& Stuart, A.J. 2009. Extinction chronology and palaeobiology of the cave bear (Ursus spelaeus). Boreas 38, 189-206. DOI 10.1111/j.1502-3885.2008.00071.x

PaZONYi, P. 2004. Mammalian ecosystem dynamics in the Carpathian Basin during the last 27,000 years. Palaeogeography, Palaeoclimatology, Palaeoecology 212, 295-314.

DOI 10.1016/j.palaeo.2004.06.008

PAZONYI, P. 2006. A Kárpát-medence kvarter emlósfauna közösségeinek paleoökológiai és rétegtani vizsgálata. $115 \mathrm{pp}$. Ph.D. thesis, Magyar Természettudományi Múzeum, Budapest, Hungary.

Price, G.J., WebB, G.E., Zhao, J.-X., Feng, Y.-X., Murray, A.S., Cooke, B.N., Hocknul, S.A. \& Sobbe, I.H. 2011. Dating megafaunal extinction on the Pleistocene Darling Downs, eastern Australia: the promise and pitfalls of dating as a test of extinction hypotheses. Quaternary Science Reviews 30, 899-914. DOI 10.1016/j.quascirev.2011.01.011

Ringer, Á., Szolyák, P., Kordos, L., Regös, J. \& Heinzlmann, K. 2006. A Herman Ottó-barlang és a Herman Ottó-kőfülke paleolit leletanyagának revíziós lehetôségei. A Herman Ottó Múzeum Évkönyve 45, 5-23.

RoSENMÜLLER, J.C. 1794. Quaedam de ossibus fossilibus animalis cuiusdam, historiam eius et cognitionem accuratiorem illustrantia. Dissertation, quam 22. Octob. 1794 ad disputandum proposuit Ioannes Christ. Rosenmüller Heßberg-Francus, LL.AA.M. in Theatro anatomico Lipsiensi Prosector assumto socio Io. Chr. Aug. Heinroth Lips. Med. Stud. Cum tabula aenea. O.V. Leipzig.

Rudner, E. \& Sümegi, P. 2001. Recurring Taiga forest-steppe habitats in the Carpathian Basin in the Upper Weichselian. Quaternary International 76/77, 177-189.

SchAFARZIK, F. 1884. Rhinoceros és Mammuth-csont leletek. Földtani Közlöny 14, 302-302.

SCHRÉTER, F. 1917. Diluviális ősemlőscsontok a pestmegyei Mende és Péczel határában. Földtani Közlöny 47, 55-56.

Schatz, A.-K., Zech, M., Buggle, B., Gulyás, S., Hambach, U., Markovic, S.B., Sümegi, P. \& Scholten, T. 2011. The late Quaternary loess record of Tokaj, Hungary: Reconstructing palaeoenvironment, vegetation and climate using stable $\mathrm{C}$ and $\mathrm{N}$ isotopes and biomarkers. Quaternary International 240, 52-61. DOI 10.1016/j.quaint.2010.10.009

Schmölcke, U. \& Zachos, F.E. 2005. Holocene distribution and extinction of the moose (Alces alces, Cervidae) in Central Europe. Mammalian Biology 70, 329-344.

DOI 10.1016/j.mambio.2005.08.001

Stuart, A.J. \& Lister, A.M. 2007. Patterns of Late Quaternary megafaunal extinctions in Europe and northern Asia. Courier Forschungsinstitut Senckenberg 259, 287-297.

SüMegi, P. \& Hertelendi, E. 1998. Reconstruction of microenvironmental changes in the Kopasz Hill loess area at Tokaj (Hungary) between 15 and $70 \mathrm{ka}$ BP. Radiocarbon 40, 855-863.
SüMegi, P. \& Krolopp, E. 2002. Quatermalacological analyses for modeling of the Upper Weichselian palaeoenvironmental changes in the Carpathian Basin. Quaternary International 91, 53-63.

Sümegi, P., Krolopp, E. \& Hertelendi, E. 1998. A SágvárLascaux interstadiális paleoökológiai rekonstrukciója. Acta geographica ac geologica et meteorologica Debrecina 34, 165-180.

Svoboda, J., PÉAn, S. \& Wojtal, P. 2005. Mammoth bone deposits and subsistence practices during Mid-Upper Palaeolithic in Central Europe: three cases from Moravia and Poland. Quaternary International 126/128, 209-221.

DOI 10.1016/j.quaint.2004.04.024

SzABó, J. 1873. Jelentés a Mammuthról Zebegényben. Földtani Közlöny 3, 58-61.

Újvári, G., Kovács, J., Varga, G., Raucsik, B. \& Markovic, S.B. 2010. Dust flux estimates for the Last Glacial Period in East Central Europe based on terrestrial records of loess deposits: a review. Quaternary Science Reviews 29, 3157-3166. DOI 10.1016/j.quascirev.2010.07.005

Varga, G., Radvánszky, B., Kovács, J. \& Katona, L. 2010. Typical Mammoth Steppe fauna remains from the southern foreland of Mecsek Mts. (Hungary). Quaternaire, Supplement 3, 199-201.

Vinogradov, A.P., Devirts, A.L., Dobkina, E.I. \& Markova, N.G. 1968. Radiocarbon dating in the Vernadsky Institute IV-V. Radiocarbon 10, 454-464.

Vogel, J.C. \& Waterbolk, H.T. 1964. Groningen radiocarbon dates V. Radiocarbon 6, 349-369.

Vogel, J.C. \& WaterbolK, H.T. 1967. Groningen radiocarbon dates VII. Radiocarbon 9, 107-155.

Vogel, J.C. \& Waterbolk, H.T. 1972. Groningen radiocarbon dates X. Radiocarbon 14, 6-110.

VöRös, I. 1981. The skulls of Mammoth in Hungary. Fragmenta Mineralogica et Palaeontologica 10, 97-106.

VöRÖS, I. 1982. Faunal remains from the Gravettian reindeer hunters' campsite at Sagvar. Folia Archaeologica 33, 43-71.

VöRös, I. 1985. Alces brevirostris Kretzoi from the Ördöglyuk Cave at Solymár (Hungary). Fragmenta Mineralogica et Palaeontologica 12, 59-66.

VöRös, I. 1987. Large mammalian faunal changes during the Late Upper Pleistocene and Early Holocene times in the Carpathian Basin, 81-102. In PÉcsI, M. (ed.) Pleistocene environment in Hungary. Geographical Research Institute HAS, Budapest.

VöRÖs, I. 1989. Madaras-Téglavető felsőpleisztocén emlős maradványai. Cumania 11, 29-44.

VöRös, I. 1991. Large mammal remains from the Upper Palaeolithic site at Esztergom-Gyurgyalag. Acta Archaeologica Hungarica 43, 261-263.

VöRÖS, I. 2000. Hunted mammals from the Gravettian campsite Bodrogkeresztúr-Henye, 113-186. In DoBosi, V.T. (ed.) Bodrogkeresztúr-Henye (NE Hungary) Upper Palaeolithic Site. Magyar Nemzeti Múzeum, Budapest. 